\title{
Isolation and characterization of micro cellulose obtained from waste mango
}

\author{
Miguel Angel Lorenzo-Santiago ${ }^{1}$ and Rodolfo Rendón-Villalobos ${ }^{2 *}$ (i) \\ ${ }^{1}$ Centro de Ciencias de Desarrollo Regional, Universidad Autónoma de Guerrero, Acapulco, Guerrero, México \\ ${ }^{2}$ Centro de Desarrollo de Productos Bióticos, Instituto Politécnico Nacional, Yautepec, Morelos, México \\ *rrendon@ipn.mx
}

\begin{abstract}
Cellulose fibers are used in polymeric matrices due to their thermal and mechanical capabilities. These biopolymers can be isolated from different natural sources. In this study, micro cellulose was obtained from mango fibrous endocarp (Mangifera caesia Jack ex Wall) waste. Isolation was performed using sulfuric acid and sodium hydroxide as removal agents of lignin and hemicellulose. A comparative analysis between native fiber (NF) and micro cellulose (MC) was performed, using FTIR, DSC and SEM techniques to assess their composition, thermal, structural and crystallinity capacities. The structures of the fibers were not damaged due to the chemical treatments received and their sizes ranged between 40 and $400 \mu \mathrm{m}$ in length. The extraction of cellulose from mango waste represents an important start in obtaining biopolymers that can be used in the food, pharmaceutical, and other industries.
\end{abstract}

Keywords: biopolymers, mango waste, micro cellulose.

How to cite: Lorenzo-Santiago, M. A., \& Rendón-Villalobos, R. (2020). Isolation and characterization of micro cellulose obtained from waste mango. Polimeros: Ciência e Tecnologia, 30(3), e2020036. https://doi.org/10.1590/0104-1428.09119

\section{Introduction}

In recent years, different ways have been sought to control and reduce pollution caused by petroleum-derived materials ${ }^{[1-3]}$, and one of the most used alternatives in the world is recycling ${ }^{[4]}$. However, and even though this conventional method reduces the ecological impact of plastic has not been possible to reduce the large volumes of those kinds of materials that are produced each year ${ }^{[5]}$. This is mainly due to the fact that a great many products are manufactured in way that make the plastic content difficult to separate and, therefore very little plastic is currently recycled. An estimated 8.3 billion metric tons of plastic are produced worldwide, and only $9 \%$ goes through recycling process ${ }^{[4]}$. Another alternative for reducing environmental impact of plastics that has been proposed is the use of polymeric materials combined with pro-oxidizing substances ${ }^{[2,6]}$. However, the wastes the materials generate after they are degraded consist of heavy metals and petroleum products ${ }^{[7-9]}$, which tend to accumulate in the environment.

To reduce the impact caused by petroleum products, there is need to look for materials that have a polymer matrix formed by biopolymers (natural polymers) ${ }^{[10]}$. Since the polymer matrix is biodegradable, the composite which is its integral part is also expected to be biodegradable and environmentally friendly ${ }^{[1]}$. It has an advantage over synthetic polymers because it can be totally biodegraded in products such as $\mathrm{CO}_{2}$, water and also organic fertilizer ${ }^{[12]}$. Bioplastics and biomaterials are composed of biopolymers, biomass derivatives or blends of natural and synthetic polymers, which will help mitigate environmental issues in the long term.

Agriculture in Mexico is an important productive sector. The role played by the agricultural sector in the other sectors of Mexico such as economic, social and environmental determines its greatest impact on the country's development. However, post-harvest residues (bagasse, husks and seeds) represent an environmental problem due to the followings: lack of distribution channels, pests, environmental policies and inadequate management of the large volumes of residues that are generated. Therefore, agricultural residues must be considered as a source sustainable and renewable of products such as cellulose fiber used as a reinforcement for bioplastics and biomaterials, due to their high availability and potential ${ }^{[13,14]}$.

Waste mango (seeds, shells and cotyledons) currently have little impact on industries. However, these wastes have been studied to obtain active and functional compounds from mango peel ${ }^{[15]}$, antioxidants from cotyledon ${ }^{[16]}$, to use fibrous endocarp in the paper industry ${ }^{[17]}$, and pulp to extract reducing sugars, organic acids and obtain alcohols ${ }^{[18]}$.

Unlike other agricultural residues, mango (Mangifera caesia Jack ex Wall) is composed of more than one biopolymer, with starch and cellulose being the highest proportion ${ }^{[19]}$. In addition to being the most abundant natural polymer in the world, cellulose is renewable, biodegradable and is a classic example of a matrix reinforcement biopolymer ${ }^{[20,21]}$ and is expected to be able to reduce and replace many non-renewable materials ${ }^{[22]}$. The fibrils have two regions 
known as crystalline (ordered regions) and amorphous (disorder regions). These regions can be hydrolysed with acid, which makes the crystalline region less reactive. This results in obtaining microfibrils, nanofibrils and cellulose nanocrystals ${ }^{[23]}$.

Cellulose fibers have an inherent structural hierarchy that originates from their different biological sources. Obtaining cellulose from different lignocellulosic fibers has attracted the interest of the scientific and industrial community in recent years ${ }^{[24,25]}$. The native fibers are longitudinal, rigid and difficult to modify due to the components that form them. These compounds work as a natural glue that gives firmness and shape. The fibers are hydrophobic. This is why, it is necessary to perform a chemical and thermal treatment, that can help to remove glue from the fibers without damaging the structure of the micro-cellulose fibers. The particle size reduction in the cellulose fibers through thermal treatment, generates major areas of contact with chemical substances such as acids and alkalis. Likewise, with the ultrasonic treatments crystallinity increase and morphology of cellulose fibers can be improved; in the same way individual fibrils could be obtained from waste mango and which serve in developing a bio-based material.

In the present study, cellulose fibers were obtained from waste mango fibrous endocarp. The shape, size and structure of the fibers were characterized as well as the decrease in lignin and hemicellulose subjected to a modified acidalkaline treatment was analysed by wet chemistry methods. Taking advantage of waste residues facilitates the use of cellulose as a biopolymer and reduces the impact generated by inappropriate disposal of agricultural waste and are able to generate profits.

\section{Materials and Methods}

\subsection{Cellulose insulation}

Fibrous endocarp of Ataulfo mango fruits (Mangifera caesia Jack ex Wall) was obtained in the local market in El Arenal, Guerrero, Mexico, and used as the raw material for this study. Reagents used to obtain and extract the native cellulose fibre (NF) and chemically modified cellulose fibre (designated micro-cellulose, MC) were: Sodium hydroxide (CAS 1310-73-2), sulfuric acid (CAS 7664-939), hydrogen peroxide (CAS 7722-84-1) and distilled water (CAS 7732-18-5).

\subsection{Pre-treatment of mango fibre}

The mango endocarp was cut into squares of approximately $1 \mathrm{~cm}^{2} .50 \mathrm{~g}$ was weighed and hydrated using distilled water. It was stirred at room temperature for two hours and subsequently dried in a continuous flow oven at $40^{\circ}$ C for 24 hours $^{[26]}$.

\subsection{Alkaline treatment}

The dried fibrous endocarp was treated in a solution of $2 \% \mathrm{NaOH}(\mathrm{w} / \mathrm{v})$ in a 1:20 ratio (fibre: solution). The solution was continuously stirred at $80^{\circ} \mathrm{C}$ for two hours. After the alkaline treatment was done, the fibres were washed with distilled water and dried at $40{ }^{\circ} \mathrm{C}$ for $24 \mathrm{~h}$. The dried fibres were grinded using a E3303.00 mini cutting mill (Eberbach Corp.), equipped with a stainless steel blades to separate the bonded fibres formed after the drying process. After the milling was completed, the fibres were stored in an airtight bag ${ }^{[27]}$.

\subsection{Whitening}

The fibres were bleached in a 1:20 ratio (fibre: solution) in a solution composed of $\mathrm{H}_{2} \mathrm{O}_{2}(\mathrm{v} / \mathrm{v})$ and $4 \% \mathrm{NaOH}(\mathrm{w} / \mathrm{v})$, and stirred for two hours at $50^{\circ} \mathrm{C}$. After the treatment, the fibres were washed with distilled water and dried at $40^{\circ}$ C for $24 \mathrm{~h}^{[28]}$.

\subsection{Acid Hydrolysis}

The fibres were subjected to $52 \%$ sulfuric acid (w/w) in a 1:20 ratio (fibre: solution), and stirred for two hours at $45^{\circ} \mathrm{C}$. The reaction was stopped by thermal shock using a vessel with distilled water at a temperature of $10^{\circ} \mathrm{C}^{[27]}$.

\subsection{Sonication}

Sonication process was applied after acid hydrolysis in order to disintegrate the fibres into microfibres in water dispersion to reduce the viscosity and allow efficient propagation of the vibration through the dispersion. Szymańska-Chargot et al. ${ }^{[29]}$ and Kasuga et al. ${ }^{[30]}$ techniques were modified and the dispersion was then subjected to sonication for $5 \mathrm{~min}$ at a power of $99 \mathrm{~W}$ using a Branson 5510MT ultrasonic cleaner. Subsequently, the samples were centrifuged at $6300 \mathrm{xg}$ at $4{ }^{\circ} \mathrm{C}$ for $15 \mathrm{~min}$ and dried at $40{ }^{\circ} \mathrm{C}$ for $24 \mathrm{~h}^{[27]}$.

\subsection{Chemical analyses}

The lignin content was determined according to Klason method ${ }^{[31]}$. The dried fibres was extracted by using Soxhlet method ${ }^{[32]}$ with ethanol-benzene solvent for $5 \mathrm{~h}$. The residue extract was oven dried at $103^{\circ} \mathrm{C}$ for $1 \mathrm{~h}$, and later treated with $72 \% \mathrm{H}_{2} \mathrm{SO}_{4}$ for $2 \mathrm{~h}$ while stirring at $37^{\circ} \mathrm{C}$. The material was then diluted to $3 \% \mathrm{H}_{2} \mathrm{SO}_{4}$ and then refluxed at $80^{\circ} \mathrm{C}$ for $4 \mathrm{~h}$; the sample was oven dried at $105^{\circ} \mathrm{C}$ for $1 \mathrm{~h}$ and cooled in a desiccator to obtain constant weight. The lignin content was calculate using the following equation ${ }^{[31]}$ :

$$
\operatorname{Lignin} \%=\frac{A 100}{W}
$$

Where $A$ is weight of lignin and $W$ is oven-dry weight of test specimen.

Holocellulose was measured by means of the Wise chlorite method ${ }^{[33]}$ through dried fibers treatment with an acidified sodium chlorite water solution in acidic medium at $70-80{ }^{\circ} \mathrm{C}$ for $1 \mathrm{~h}$. The process was repeated until the product became white. Determination of cellulose to dry fiber samples was using the Seifert method ${ }^{[34]}$ wherein the cellulose is separated from the plant material in the process of its processing with aqueous solutions of acetylacetone, dioxane, and hydrochloric acid. Hemicellulose content was calculated theoretically from the difference in the contents of holocellulose and cellulose. 


\subsection{Scanning Electron Microscopy (SEM)}

Cellulose samples were sprinkled on a double adhesion carbon conductive tape, which was previously fixed on aluminium support of the scanning electron microscope Carl Zeiss EVO LS 10. Subsequently, they were observed at a voltage of $2.5 \mathrm{kV}$, with a resolution of 3-10 nm; the micrographs were taken at 100,500 and 1500 magnifications ${ }^{[35]}$.

\subsection{Fourier Transform Infrared Spectroscopy (FTIR)}

Fourier transform infrared spectroscopy (FTIR) studies were carried out using a Perkin-Elmer-Spectrum 100/100 N FT-IR infrared spectrometer. The infrared region was within a range of $4000-650 \mathrm{~cm}^{-1}$ in the transmittance mode, with a resolution of $16 \mathrm{~cm}^{-1}$ and 8 scans $^{[36]}$.

\subsection{Differential Scanning Calorimetry (DSC)}

A differential scanning calorimeter model TA 2010 was used. The equipment was calibrated with indium (melting point of $156.4^{\circ} \mathrm{C}$ and enthalpy of $6.8 \mathrm{cal} / \mathrm{g}$ ). Between 5 and $10 \mathrm{mg}$ of the sample was weighed, using a micro balance with an accuracy of $\pm 0.01 \mathrm{mg}$, a heating program ranging from 20 to $400^{\circ} \mathrm{C}$ and a heating rate of $10^{\circ} \mathrm{C} / \mathrm{min}^{[30]}$. This generated an inert atmosphere in the cell by circulating $50 \mathrm{~mL} / \mathrm{min}$ of nitrogen gas ( $99.9 \%$ purity).

\subsection{Crystallinity}

The degree of crystallinity was determined based on the DSC enthalpy of fusion data using the following equation ${ }^{[37]}$ :

$$
X_{c}=\frac{\Delta H_{f}}{\Delta H_{o}}
$$

Where $X_{C}$ is the crystalline fraction, $\Delta \mathrm{H}_{F}$ represents the enthalpy of fusion measured by DSC and $\Delta \mathrm{H}_{O}$ is the enthalpy of fusion for $100 \%$ crystalline polymer.

\section{Results and Discussions}

\subsection{Chemical Analyses}

Despite the economic importance of agricultural residues there are no studies on the chemical composition of the mango endocarp. In general, the studies of mango chemistry are limited to chemical characteristics based mainly on mango agroindustrial waste, fruit by-products and silage ${ }^{[38-41]}$.

The results of lignin and calculated hemicellulose of native (NF) and alkaline modified (MC) fibers decreased, from $10.32 \mathrm{wt} \%$ to $0.64 \mathrm{wt} \%$ for NF and $29.75 \mathrm{wt} \%$ to $1.11 \mathrm{wt} \%$, respectively. Regarding the lignin content, the data from this investigation $(10.32 \mathrm{wt} \%)$ is close to those found for Guzmán et al. ${ }^{[38]}$, different values are obtained when the food-processing industry method is employed $(10.32 \mathrm{wt} \% \mathrm{vs}$. $9.0 \mathrm{wt} \%$ ). This method is similar to Klason lignin extraction process, except a final step of $1 \mathrm{~h}$ of calcination at $550^{\circ} \mathrm{C}$. Nevertheless, a large difference is observed between our lignin results: $5.76 \mathrm{wt} \%$ and $6.97 \mathrm{wt} \%$ of lignin in mango peel and mango by-products, respectively ${ }^{[39,40]}$. Concerning the hemicellulose content from this study $(29.75 \mathrm{wt} \%)$ is lower than the values ( $31.1 \mathrm{wt} \%$ and $31.75 \mathrm{wt} \%$ ) found for mango peel and mango by-products ${ }^{[38,41]}$. This can be explained by the fact that it seems that in the foodprocessing industry method, the neutral detergent solution used for determining the Neutral Detergent Fibre (NDF $=$ Hemicellulose + Cellulose + Lignin) content does not remove completely hemicelluloses and is, therefore, this method is not indicated for this work.

\subsection{Structural characterization}

The native fibres presented very dense outer layers covering the cellulose sacs. The layers are considered to be composed of lignin (Figure 1a). Lignin wraps the cellulose in the inner part covering it with its stiffness and hardness property. Small globular particles and pores along the fibres and impurities can be seen on the surface.

Figure $1 \mathrm{~b}$ shows an accumulation of long fibres, rolled and small traces of waste. This is attributed to the modification of the alkaline treatment using $\mathrm{NaOH}$. Cellulose fibres can be seen more clearly, but there is still a need to remove part of the lignin and hemicellulose that holds them together. Cellulose fibres are more available due to the removal of lignin, and their characteristics (e.g. shape, surface) are similar to those of the commercially available cellulose (Civeq $^{\mathrm{TM}}$ ); the SEM images (Figure $1 \mathrm{~b}$ and $\mathrm{c}$ ) evidence that separate individual fibres have also similar morphologies with smooth surfaces.

The fibres went through a whitening process with the help of hydrogen peroxide. The peroxide helped in eliminating some waxes, tannins, lignin and alkaline treatment residues.

In Figure 2a, completely separated fibres can be seen; there are no traces of lignin, as well as porous components. In this procedure, the decrease in thickness, shape, size and discoloration of the fibres is more evident. After bleaching, the fibres had sizes ranging from 40 to $400 \mu \mathrm{m}$ in length with a uniform surface and rectangular shape (Figure $2 b$ ). Owi et al. ${ }^{[42]}$ characterized micro celluloses chemically isolated from fruit bunches and sugarcane bagasse as well as commercial cellulose (Sigma ${ }^{\mathrm{TM}}$ ) with characteristics similar to those obtained in this study after extraction, particularly in fibre shape and surface. In a similar manner, Nagalakshmaiah et al. ${ }^{[43]}$ report the shape and diameter of chili fibres by an acid hydrolysis treatment. These results are consistent with the ones presented in this study. This is consistent with the report of Atiqah et al. ${ }^{[4]}$ that amorphous portions like hemicellulose and lignin were removed after applying alkali and bleaching treatment on raw kenaf fibre.

\subsection{FTIR analysis}

Figure 3 shows the native and micro cellulose fibre spectra obtained by chemical treatment. A peak at $894 \mathrm{~cm}^{-1}$ can be observed in the fibres with alkaline treatment. This signal is attributed to the anomeric carbon present in cellulose. This signal is usually in the polysaccharide absorbing region of $950-700 \mathrm{~cm}^{-1[45]}$, which also reveals the component structures of $\beta$-glucans. In the native fibre, this signal is less intense because the lignin coating prevents specific cellulose signals that are present.

A narrow absorption band in the region between 1170 and $920 \mathrm{~cm}^{-1}$ ascribed to the polysaccharide bands, shows the stretching vibrations of $\mathrm{C}-\mathrm{O}, \mathrm{C}-\mathrm{C}$ and $\mathrm{C}-\mathrm{OH}$ bonds which 

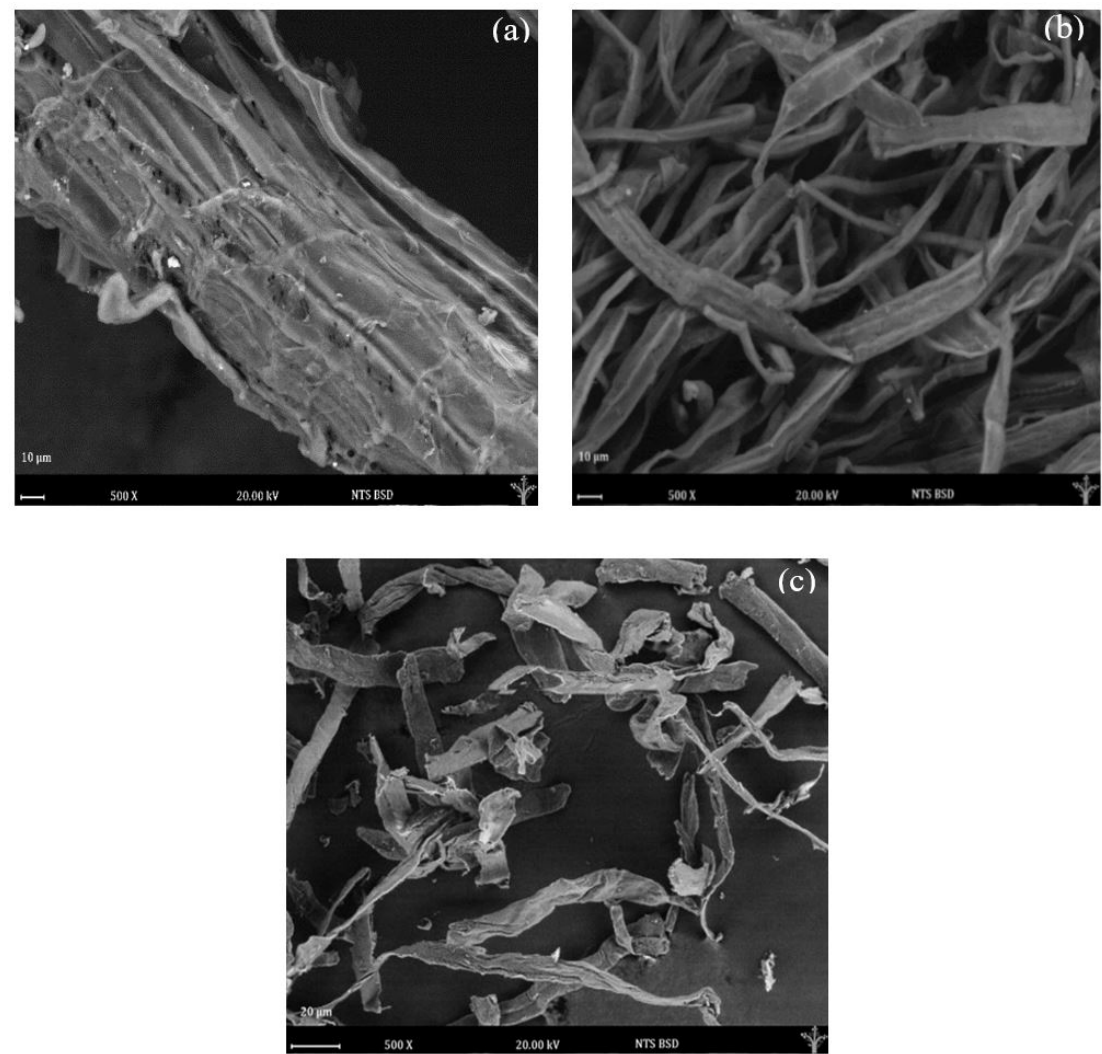

Figure 1. Micrograph of (a) native mango fiber, (b) alkaline modified fiber (c) commercial cellulose (Civeq ${ }^{\mathrm{TM}}$ ).
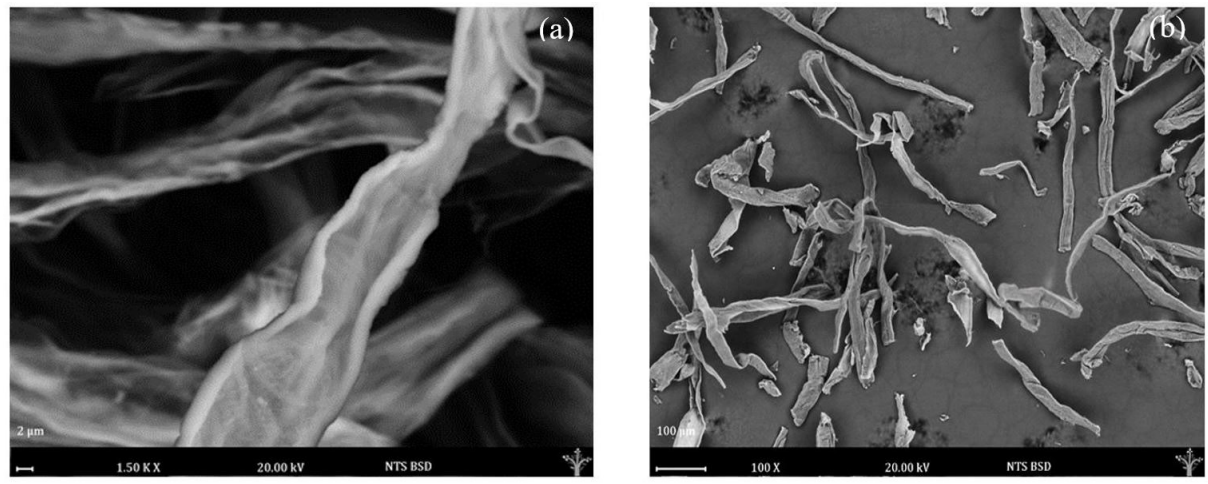

Figure 2. Micrographs of (a) fiber after whitening (b) and thermal sonication.

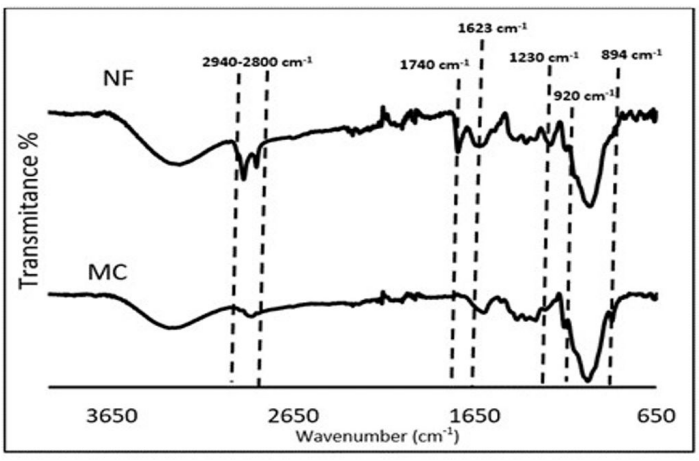

Figure 3. Infrared spectra for native fibre (NF) and micro cellulose (MC). are in cellulose, lignin and hemicellulose ${ }^{[46,47]}$. A strong signal was present in the treated fibre (MC). The increase is based on the breaking of bonds during the acid-base treatment.

The native fibre showed a peak at $1230 \mathrm{~cm}^{-1}$. This is attributed to the stretching of $\mathrm{C}-\mathrm{O}-\mathrm{C}$ bonds of the alkyl-aryl ether, a compound present in the structure of lignin, and which disappears after chemical treatments. This means that the lignin was partially removed in $\mathrm{MC}$ as further confirmed by lignin results obtained in this work, 0.64 wt \%, determined by Klason method.

In the native fibre, a characteristic peak of the $\mathrm{C}-\mathrm{C}$ unsaturated bond of lignin was observed at $1623 \mathrm{~cm}^{-1}$, as well as the water band at $1636 \mathrm{~cm}^{-1}$ decreasing its intensity slightly in MC. Likewise, a peak of $1740 \mathrm{~cm}^{-1}$ is observed, 
which is associated with the stretching of $\mathrm{C}=\mathrm{O}$ groups linked to aliphatic carboxylic acid and ketone. It could also be related to the presence of hemicellulose ${ }^{[48]}$. Both peaks decrease when the sample is subjected to acid treatment, which allows the removal of lignin and hemicellulose, from 10.32 to $0.64 \mathrm{wt} \%$ and from 29.75 to $1.11 \mathrm{wt} \%$, respectively.

Between the range of 2940 and $2800 \mathrm{~cm}^{-1}$, there are two peaks in the native cellulose, which are assigned to the asymmetrical and symmetrical stretching vibrations of alkyl, aliphatic and aromatic rings $(\mathrm{H}-\mathrm{C}-\mathrm{H})$ groups present in hemicellulose and lignin. These bands were ascribed to the aliphatic materials such as cutin, waxes and cutan ${ }^{[49]}$. The signal decreases when the sample is subjected to an acid-base treatment, due to the removal of these components ${ }^{[38]} .1740 \mathrm{~cm}^{-1}$ band associated with the stretching of $\mathrm{C}=\mathrm{O}$ in ester groups disappeared after basic hydrolysis, confirming the partial removal of hemicellulose, which presented variation in hemicellulose content (e.g. $1.11 \mathrm{wt} \%$ compared to $29.75 \mathrm{wt} \%$ for NF sample).

\subsection{Thermal characterization}

As for the DSC results, both samples studied in nitrogen atmosphere show a similar trend and, all the reactions during the decomposition of the cellulose were endothermic process in inert atmosphere (Figure 4). The native endocarp fibre presented three steps of thermal degradation in relation to cellulose, lignin and hemicellulose. This is in line with a research done by Stevulova et al. ${ }^{[50]}$.

NF shows an endotherm at $113.64{ }^{\circ} \mathrm{C}$ and a plateau at $145.3{ }^{\circ} \mathrm{C}$; while that of $\mathrm{MC}$ is at $135.11^{\circ} \mathrm{C}$. This is mainly due to the elimination of moisture by the heat range applied in the DSC, as well as reducing sugars and other volatile components joined to the fibres, that are thermally decomposed. Espinosa-Andrews and Urias-Silvas ${ }^{[51]}$ mention that there is a humidity loss, specifically in fructans, in temperatures under $130{ }^{\circ} \mathrm{C}$. In addition to this, a small endotherm at $232.12^{\circ} \mathrm{C}$ can be observed in NF probably due to the degradation of hemicellulose, reducing sugars and those hemicelluloses that are still joined to the cellulose-lignin complex ${ }^{[48]}$. $\mathrm{NF}$ and $\mathrm{MC}$ presented endotherm peaks at $325.52{ }^{\circ} \mathrm{C}$ and $335.25^{\circ} \mathrm{C}$, respectively. The endothermic peak observed in a $220-370{ }^{\circ} \mathrm{C}$ temperature range corresponds to that used for the simultaneous decomposition of hemicelluloses, cellulose and lignin. Based on the report of Miyahara et al. ${ }^{[52]}$, this endothermic peak represents the degradation of hemicellulose. As reported by Xiao et al. ${ }^{[53]}$, cellulose is degraded within the range of 250 and $345^{\circ} \mathrm{C}$.

The enthalpies in the initial endotherm peak of the NF sample $(121.92 \mathrm{~J} / \mathrm{g})$ are lower compared to those of the MC sample $(183.27 \mathrm{~J} / \mathrm{g})$. This could be due to a greater presence of traces of waste and volatile components that were impregnated through acid-alkali hydrolysis. Therefore, a greater amount of heat energy is needed for degradation to occur. Conversely, with respect to final endotherm peak for both samples, the enthalpy of MC $(172.92 \mathrm{~J} / \mathrm{g})$ is lower compared to that of the native fibre $(178.32 \mathrm{~J} / \mathrm{g})$, which could be due to the elimination of larger sugar chains through acid-alkali hydrolysis. Besides, under nitrogen atmosphere, cellulose is more resistant to thermal treatment, probably due to its crystalline structure ${ }^{[50]}$. The range at which lignin is

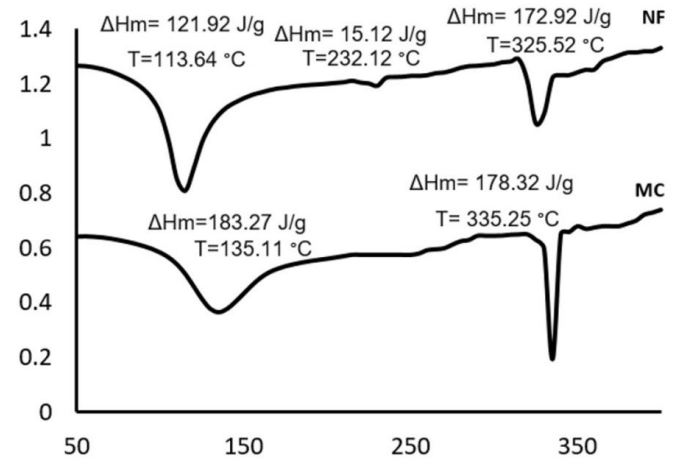

Figure 4. DCS curves of native (NF) and modified (MC) fibre.

Table 1. Percentage of crystallinity of native fibre (NF) and microcellulose (MC).

\begin{tabular}{cc}
\hline Sample & Crystallinity \% \\
\hline NF & 75.18 \\
MC & 77.53 \\
\hline
\end{tabular}

decomposed is between 250 and $600^{\circ} \mathrm{C}$. The analysis was performed up to $400^{\circ} \mathrm{C}$, which indicates the degradation of $40 \%$ of the total lignin in the native sample. In the composition of native cellulose, it can be seen that the compound that degrades first is hemicellulose, followed by cellulose and lignin ${ }^{[53]}$.

\subsection{Crystallinity}

Applying the Equation 1 and with the use of the DSC enthalpy of fusion and taking $230 \mathrm{~J} / \mathrm{g}$ as the value for the fully crystalline Polycaprolactam (PA6) ${ }^{[54]}$, a lower value of crystallinity for native fibre (NF) was found compared to microcellulose (MC) (Table 1).

As reported by Li et al. ${ }^{[55]}$, the percentage of crystallinity in native fibre will always be lower, due to the presence of hemicellulose and lignin, amorphous compounds that encapsulate the fibrils. It is believed that the crystallinity index in micro cellulose increases due to the elimination of the amorphous regions of cellulose, in which hydrolysis drives the breakdown of glycosidic bonds, releasing individual crystals ${ }^{[56]}$. The crystallinity of mango micro cellulose reported in this study is similar to that reported by Bolio-López et al. ${ }^{[57]}$ in banana peel micro cellulose $(72 \%$ crystallinity) but greater than that obtained by Naranjo et al. ${ }^{[47]}$ in agave fibre $(50.07 \%)$. The greater the crystallinity of a fibre, the better the thermal stability and properties it can provide in a polyblend to obtain biodegradable materials ${ }^{[58]}$.

\section{Conclusions}

Cellulose microfibers were isolated from waste mango fibrous endocarp (Mangifera caesia Jack ex Wall), after which they were subjected to an acid-alkaline treatment and an ultrasonic treatment that helped homogenize their sizes. The acid-alkaline treatment helped decrease the size of the fibres and was also involved in the removal of lignin and cellulose. Ultrasonication process is a very effective way to depolymerize cellulose and that led to reduce the formation 
of agglomeration and increase the dispersion of cellulose disintegrating into individual microfibers. We hope that with this simple chemical-ultrasonic treatment applied to cellulose will further stimulate interest in isolating microcellulose fibers from natural sources. The use of agricultural waste as a natural source of biopolymers has become an excellent option for innovation and the development of new products with potentially biodegradable properties by having a polymeric matrix formed by biopolymers and, their utilization can minimize negative environmental effects.

\section{References}

1. Derraik, J. G. (2002). The pollution of the marine environment by plastic debris: a review. Marine Pollution Bulletin, 44(9), 842-852. http://dx.doi.org/10.1016/S0025-326X(02)00220-5. PMid:12405208.

2. O'Brine, T., \& Thompson, R. C. (2010). Degradation of plastic carrier bags in the marine environment. Marine Pollution Bulletin, 60(1), 2279-2283. https://doi.org/10.1016/j. marpolbul.2010.08.005.

3. Webb, H. K., Arnott, J., Crawford, R. J., \& Ivanova, E. P. (2012). Plastic degradation and its environmental implications with special reference to poly (ethylene terephthalate). Polymers, 5(1), 1-18. https://doi.org/10.3390/polym5010001.

4. Das, O., Sarmah, A. K., \& Bhattacharyya, D. (2015). A sustainable and resilient approach through biochar addition in wood polymer composites. The Science of the Total Environment, 512-513, 326-336. http://dx.doi.org/10.1016/j.scitotenv.2015.01.063. PMid:25634737.

5. Geyer, R., Jambeck, J. R., \& Law, K. L. (2017). Production, use, and fate of all plastics ever made. Science advances, 3(7), e1700782. https://doi.org/10.1126/sciadv.1700782.

6. Ojeda, T. F., Dalmolin, E., Forte, M. M., Jacques, R. J., Bento, F. M. \& Camargo, F. A. (2009). Abiotic and biotic degradation of oxo-biodegradable polyethylenes. Polymer degradation and stability, 94(6), 965-970. https://doi.org/10.1016/j. polymdegradstab.2009.03.011.

7. Wiles, D. M., \& Scott, G. (2006). Polyolefins with controlled environmental degradability. Polymer degradation and stability, 91(7), 1581-1592. https://doi.org/10.1016/j. polymdegradstab.2005.09.010.

8. Kyrikou, I., \& Briassoulis, D. (2007). Biodegradation of agricultural plastic films: a critical review. Journal of Polymers and the Environment, 15(2), 125-150. https://doi.org/10.1007/ s10924-007-0053-8.

9. Ammala, A., Bateman, S., Dean, K., Petinakis, E., Sangwan, P., Wong, S., \& Leong, K. H. (2011). An overview of degradable and biodegradable polyolefins. Progress in Polymer Science, 36(8), 1015-1049. https://doi.org/10.1016/j.progpolymsci.2010.12.002.

10. Flieger, M., Kantorova, M., Prell, A., Řezanka, T., \& Votruba, J. (2003). Biodegradable plastics from renewable sources. Folia Microbiologica, 48(1), 27-44. http://dx.doi.org/10.1007/ BF02931273. PMid:12744074.

11. Sagnelli, D., Hooshmand, K., Kemmer, G. C., Kirkensgaard, J. J. K., Mortensen, K., Giosafatto, C. V. L., Holse, M., Hebelstrup, K. H., Bao, J., Stelte, W., Bjerre, A. B., \& Blennow, A. (2017). Cross-linked amylose bio-plastic: a transgenic-based compostable plastic alternative. International Journal of Molecular Sciences, 18(10), 2075-2086. http://dx.doi.org/10.3390/ijms18102075. PMid:28973963.

12. Bastioli, C. (2001). Global status of the production of biobased packaging materials. Starch, 53(8), 351-355. https://doi.org/10.1002/1521-379X(200108)53:8<351::AIDSTAR351>3.0.CO;2-R.
13. Burgos, N., Valdés, A., \& Jiménez, A. (2016). Valorization of agricultural wastes for the production of protein-based biopolymers. Journal of Renewable Materials, 4(3), 165-177. http://dx.doi.org/10.7569/JRM.2016.634108.

14. Vestena, M., Gross, I. P., Muller, C. M. O., \& Pires, A. T. N. (2016). Isolation of whiskers from natural sources and their dispersed in a non-aqueous medium. Polímeros: Ciência e Tecnologia, 26(4), 327-335. http://dx.doi.org/10.1590/01041428.2367.

15. Serna-Cock, L., García-Gonzales, E., \& Torres-León, C. (2016). Agro-industrial potential of the mango peel based on its nutritional and functional properties. Food Reviews International, 32(4), 364-376. http://dx.doi.org/10.1080/875 59129.2015.1094815.

16. Torres-León, C., Rojas, R., Serna-Cock, L., Belmares-Cerda, R., \& Aguilar, C. N. (2017). Extraction of antioxidants from mango seed kernel: optimization assisted by microwave. Food and Bioproducts Processing, 105, 188-196. http://dx.doi. org/10.1016/j.fbp.2017.07.005.

17. Cordeiro, E. M. S., Nunes, Y. L., Mattos, A. L. A., Rosa, M. F., de sá M. Sousa, M., Fo., \& Ito, E. N. (2014). Polymer biocomposites and nanobiocomposites obtained from mango seeds. Macromolecular Symposia, 344(1), 39-54. Macromolecular Symposia, 344(1), 39-54. http://dx.doi. org/10.1002/masy.201300217.

18. Giraldo, L. M., Correa, H. M., Gutiérrez, J. B., \& Castano, C. (2007). Aprovechamiento del residuo agroindustrial del mango común (Mangifera indica L.) en la obtención de azúcares fermentables. Ingeniería y Ciencia-ing, 3(6), 41-62.

19. Lorenzo-Santiago, M. A., Juárez-López, A. L., Rosas-Acevedo, J. L., Rendón-Villalobos, J. R., Toribio-Jiménez, J., \& García Hernández, E. (2018). Management and final disposal of mango waste in the State of Guerrero, Mexico: a brief review. The Journal of Agricultural Science, 10(12), 34-41. http://dx.doi. org/10.5539/jas.v10n12p34.

20. Béguin, P., \& Aubert, J.-P. (1994). The biological degradation of cellulose. FEMS Microbiology Reviews, 13(1), 25-58. http:// dx.doi.org/10.1111/j.1574-6976.1994.tb00033.x. PMid:8117466.

21. Azizi Samir, M. A. S., Alloin, F., \& Dufresne, A. (2005). Review of recent research into cellulosic whiskers, their properties and their application in nanocomposite field. Biomacromolecules, 6(2), 612-26. http://dx.doi.org/10.1021/ bm0493685. PMid:15762621.

22. Wegner, T. H., \& Jones, P. E. (2006). Advancing cellulosebased nanotechnology. Cellulose (London, England), 13(2), 115-118. http://dx.doi.org/10.1007/s10570-006-9056-1.

23. Beck-Candanedo, S., Roman, M., \& Gray, D. G. (2005). Effect of reaction conditions on the properties and behavior of wood cellulose nanocrystal suspensions. Biomacromolecules, 6(2), 1048-1054. http://dx.doi.org/10.1021/bm049300p. PMid:15762677.

24. Cerqueira, J. C., Penha, J. D. S., Oliveira, R. S., Guarieiro, L. L. N., Melo, P. D. S., Viana, J. D., \& Machado, B. A. S. (2017). Production of biodegradable starch nanocomposites using cellulose nanocrystals extracted from coconut fibers. Polímeros: Ciência e Tecnologia, 27(4), 320-329. http://dx.doi. org/10.1590/0104-1428.05316.

25. Khenblouche, A., Bechki, D., Gouamid, M., Charradi, K., Segni, L., Hadjadj, M., \& Boughali, S. (2019). Extraction and characterization of cellulose microfibers from Retama raetam stems. Polímeros: Ciência e Tecnologia, 29(1), e2019011. http://dx.doi.org/10.1590/0104-1428.05218.

26. Salgado-Delgado, R., Coria-Cortés, L., García-Hernández, E., Galarza, Z. V., Rubio-Rosas, E., \& Crispín-Espino, I. (2010). Elaboración de materiales reforzados con carácter biodegradable a partir de polietileno de baja densidad y bagazo 
de caña modificado. Revista Iberoamericana de Polímeros, 11(7), 520-531. Retrieved in 2019, October 28, from https:// dialnet.unirioja.es/servlet/articulo?codigo $=3694228$

27. Cordeiro, E. M. S., Nunes, Y. L., Mattos, A. L., \& Rosa, M. F., Souza, M. S. M., Fo., \& Ito, E. N. (2014). Polymer biocomposites and nanobiocomposites obtained from mango seeds. Macromolecular Symposia, 344(1), 39-54. https://doi. org/10.1002/masy.201300217.

28. Orts, W. J., Shey, J., Imam, S. H., Glenn, G. M., Guttman, M. E., \& Revol, J. F. (2005). Application of cellulose microfibrils in polymer nanocomposites. Journal of Polymers and the Environment, 13(4), 301-306. http://dx.doi.org/10.1007/ s10924-005-5514-3.

29. Szymańska-Chargot, M., Cieśla, J., Chylińska, M., Gdula, K., Pieczywek, P. M., Koziol, A., Cieślak, K. J., \& Zdunek, A. (2018). Effect of ultrasonication on physicochemical properties of apple based nanocellulose-calcium carbonate composites. Cellulose (London, England), 25(8), 4603-4621. http://dx.doi. org/10.1007/s10570-018-1900-6.

30. Kasuga, T., Isobe, N., Yagyu, H., Koga, H., \& Nogi, M. (2018). Clearly transparent nanopaper from highly concentrated cellulose nanofiber dispersion using dilution and sonication. Nanomaterials (Basel, Switzerland), 8(2), 104. http://dx.doi. org/10.3390/nano8020104. PMid:29439544.

31. Technical Association of the Pulp and Paper Industry - TAPPI. (2007). Acid insoluble lignin in wood and pulp. T 222 om-02. Fibrous materials and pulp testing. Atlanta: TAPPI.

32. Technical Association of the Pulp and Paper Industry - TAPPI. (2007). Solvent extractives of wood and pulp. T $204 \mathrm{~cm}-97$. Fibrous materials and pulp testing. Atlanta: TAPPI.

33. Haykiri-Acma, H., Yaman, S., Alkan, M., \& Kucukbayrak, S. (2014). Mineralogical characterization of chemically isolated ingredients from biomass. Energy Conversion and Management, 77,221-226. http://dx.doi.org/10.1016/j.enconman.2013.09.024.

34. Waliszewska, B., Mleczek, M., Zborowska, M., Goliński, P., Rutkowski, P., \& Szentner, K. (2019). Changes in the chemical composition and the structure of cellulose and lignin in elm wood exposed to various forms of arsenic. Cellulose (London, England), 26(10), 6303-6315. http://dx.doi.org/10.1007/ s10570-019-02511-z.

35. Rendón-Villalobos, R., García-Hernández, E., GüizadoRodríguez, M., Salgado Delgado, R., \& Rangel-Vázquez, N. A. (2010). Obtención y caracterización de almidón de plátano (Musa paradisiaca L.) acetilado a diferentes grados de sustitución. Afinidad, 67(548), 294-300. Retrieved in 2019, October 28, from https://www.raco.cat/index.php/afinidad / article/view/269205/356773

36. Xu, Y. X., Miladinov, V., \& Hanna, M. A. (2004). Synthesis and characterization of starch acetates with high substitution. Cereal Chemistry, 81(6), 735-740. http://dx.doi.org/10.1094/ CCHEM.2004.81.6.735.

37. Poley, L. H., Siqueira, A. P. L., Silva, M. G., Vargas, H., \& Sanchez, R. (2004). Photothermal characterization of low density polyethylene food packages. Polimeros: Ciência e Tecnologia, 14(1), 8-12. http://dx.doi.org/10.1590/S010414282004000100007.

38. Guzmán, O., Lemus, C., Martínez, S., Bonilla, J., Plasencia, A., \& Ly, J. (2012). Chemical characteristics of silages of mango (Mangifera indica L.) by-products for animal feeding. Canadian Journal of Agricultural Science, 46(4), 369-374.

39. de Carvalho Couto, C. C., Fo., da Silva, J. C., Fo., Prata Neiva, A., Jr.,Magalhães de Souza, R., Rodrigues Nunes, J. A., \& Viana Coelho, J. (2010). Fibrous fractions of mango residue silage with additives. Ciência e Agrotecnologia, 34(3), 751757. http://dx.doi.org/10.1590/S1413-70542010000300031.
40. Serna Cock, L., \& Torres León, C. (2014). Potencial agroindustrial de cáscaras de mango de las variedades Keitt, y Tommy Atkins (Mangifera indica). Acta Agronomica, 64(2), 110-115. http:// dx.doi.org/10.15446/acag.v64n2.43579.

41. Balza, M., Garrido, E., García, M., Martínez, J., \& García, A. (2017). Chemical characterization of the cellular wall of mango bocado pulp. Revista Agrollanía, 14, 7-13.

42. Owi, W. T., Lin, O. H., Sam, S. T., Chia, C. H., Zakaria, S., Mohaiyiddin, M. S., Villagracia, A. R., Santos, G. N., \& Md Akil, H. (2016). Comparative study of microcelluloses isolated from two different biomasses with commercial cellulose. BioResources, 11(2), 3453-3465. http://dx.doi.org/10.15376/ biores.11.2.3453-3465.

43. Nagalakshmaiah, M., El Kissi, N., Mortha, G., \& Dufresne, A. (2016). Structural investigation of cellulose nanocrystals extracted from chili leftover and their reinforcement in cariflexIR rubber latex. Carbohydrate Polymers, 136, 945-954. http:// dx.doi.org/10.1016/j.carbpol.2015.09.096. PMid:26572433.

44. Atiqah, M. S. N., Gopakumar, D. A., F A T, O., Pottathara, Y. B., Rizal, S., Aprilia, N. A. S., Hermawan, D., Paridah, M. T. T., Thomas, S., \& H P S, A. K. (2019). Extraction of cellulose nanofibers via eco-friendly supercritical carbon dioxide treatment followed by mild acid hydrolysis and the fabrication of cellulose nanopapers. Polymers, 11(11), 1813. PMid:31694184.

45. Sun, J. X., Xu, F., Sun, X. F., Xiao, B., \& Sun, R. C. (2005). Physico-chemical and thermal characterization of cellulose from barley straw. Polymer Degradation \& Stability, 88(3), 521-531. http://dx.doi.org/10.1016/j.polymdegradstab.2004.12.013.

46. Yang, H., Yan, R., Chen, H., Lee, D. H., \& Zheng, C. (2007). Characteristics of hemicellulose, cellulose and lignin pyrolysis. Fuel, 86(12-13), 1781-1788. http://dx.doi.org/10.1016/j. fuel.2006.12.013.

47. Naranjo, D. C., Alamilla-Beltran, L., Gutierrez-Lopez, G. F., Terres-Rojas, E., Solorza-Feria, J., Romero-Vargas, S., Yee-Madeira, H., Flores-Morales, A., \& Mora-Escobedo, R. (2016). Isolation and characterization of cellulose obtained from Agave salmiana fibers using two acid-alkali extraction methods. Revista Mexicana de Ciencias Agricolas, 7(1), 31-43. http://dx.doi.org/10.29312/remexca.v7i1.368.

48. Sgriccia, N., Hawley, M. C., \& Misra, M. (2008). Characterization of natural fiber surfaces and natural fiber composites. Composites. Part A, Applied Science and Manufacturing, 39(10), 1632-1637. http://dx.doi.org/10.1016/j.compositesa.2008.07.007.

49. Heredia-Guerrero, J. A., Benítez, J. J., Domínguez, E., Bayer, I. S., Cingolani, R., Athanassiou, A., \& Heredia, A. (2014). Infrared and Raman spectroscopic features of plant cuticles: a review. Frontiers in Plant Science, 5, 305. http://dx.doi. org/10.3389/fpls.2014.00305. PMid:25009549.

50. Stevulova, N., Estokova, A., Cigasova, J., Schwarzova, I., Kacik, F., \& Geffert, A. (2017). Thermal degradation of natural and treated hemp hurds under air and nitrogen atmosphere. Journal of Thermal Analysis and Calorimetry, 128(3), 16491660. http://dx.doi.org/10.1007/s10973-016-6044-z.

51. Espinosa-Andrews, H., \& Urias-Silvas, J. E. (2012). Thermal properties of agave fructans (Agave tequilana Weber var. Azul). Carbohydrate Polymers, 87(4), 2671-2676. http://dx.doi. org/10.1016/j.carbpol.2011.11.053.

52. Miyahara, R. Y., Melquiades, F. L., Ligowski, E., Santos, A., Fávaro, S. L., \& Antunes, O. R., Jr. (2018). Preparation and characterization of composites from plastic waste and sugar cane fiber. Polímeros: Ciência e Tecnologia, 28(2), 147-154. http://dx.doi.org/10.1590/0104-1428.12216.

53. Xiao, B., Sun, X., \& Sun, R. (2001). Chemical, structural, and thermal characterizations of alkali-soluble lignins and hemicelluloses, and cellulose from maize stems, rye straw, and 
rice straw. Polymer Degradation \& Stability, 74(2), 307-319. http://dx.doi.org/10.1016/S0141-3910(01)00163-X.

54. Wunderlich, B. (1990). Thermal analysis. New York: Academic Press. http://dx.doi.org/10.1016/B978-0-12-765605-2.50006-6.

55. Li, Q., Zhou, J., \& Zhang, L. (2009). Structure and properties of the nanocomposite films of chitosan reinforced with cellulose whiskers. Journal of Polymer Science. Part B, Polymer Physics, 47(11), 1069-1077. http://dx.doi.org/10.1002/polb.21711.

56. Spagnol, C., Rodrigues, F. H. A., Pereira, A. G. B., Fajardo, A. R., Rubira, A. F., \& Muniz, E. C. (2012). Superabsorbent hydrogel composite made of cellulose nanofibrils and chitosangraft-poly (acrylic acid). Carbohydrate Polymers, 87(3), 2038-2045. http://dx.doi.org/10.1016/j.carbpol.2011.10.017.
57. Bolio-López, G. I., Valadez-González, A., Veleva, L., \& Andreeva, A. (2011). Cellulose whiskers from agro-industrial banana wastes: isolation and characterization. Revista Mexicana de Ingeniería Química, 10(2), 291-299.

58. Klemm, D., Heublein, B., Fink, H. P., \& Bohn, A. (2005). Cellulose: fascinating biopolymer and sustainable raw material. Angewandte Chemie International Edition, 44(22), 3358-3393. http://dx.doi.org/10.1002/anie.200460587. PMid:15861454.

Received: Oct. 28, 2019

Revised: Sept. 28, 2020

Accepted: Nov. 17, 2020 